\title{
Jesus in Judea
}

\begin{abstract}
Author:
Johannes Beutler ${ }^{1}$

Affiliation:

${ }^{1}$ Theologische Hochschule Sankt Georgen Frankfurt am

Main, Germany

Correspondence to:

Johannes Beutler

Email:

johannes.beutler@jesuiten. org

Postal address:

Elsheimer Street 9, D-60322

Frankfurt, Germany

Dates:

Received: 15 Jan. 2015

Accepted: 22 June 2015

Published: 14 Aug. 2015

How to cite this article:

Beutler, J., 2015, 'Jesus in

Judea', In die Skriflig 49(2),

Art. \#1926, 6 pages. http://

dx.doi.org/10.4102/ids.

v49i2.1926

\section{Copyright:}

C 2015. The Authors. Licensee: AOSIS

OpenJournals. This work is licensed under the Creative Commons Attribution License.
\end{abstract}

\section{Read online:}

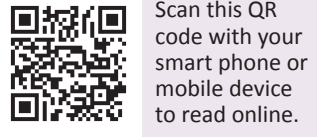

Jesus' mission in Judea (Jn 3:22-36) finds little attention paid to the geographical setting of this mission. Connected with this lack of interest is the question regarding a 'Jew' with whom the disciples of John the Baptist are reported to be in controversy according to John 3:25. A look at the geographical structure of Jesus' mission in John 2:13-4:54 may throw new light on these issues. Apparently, the mission of Jesus in this section of the Fourth Gospel follows a geographical scheme similar to the one outlined in Acts 1:8: the disciples are to be the witnesses of Jesus in Jerusalem and in all Judea and Samaria and until the end of the earth. Different from this outline, Jesus' mission, according to John, leads him to Galilee. All God's people are to hear his preaching and come to faith before the great controversies with the leaders of the Jewish people in John 5-10. If a mission of Jesus in Judea forms part of his mission to Israel,

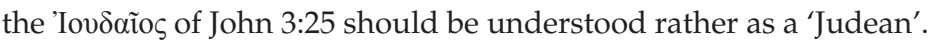

Jesus in Judea. Daar is tot onlangs nie veel aandag aan die geografiese agtergrond van Jesus se sending in Judea geskenk nie. Saam met hierdie gebrek aan belangstelling is die vraagstuk ten opsigte van die sogenaamde 'Jood' wat volgens Johannes 3:25 in 'n argument met die dissipels van Johannes die Doper betrokke was. 'n Blik op die geografiese agtergrond van Jesus se sending volgens Johannes 2:13-4:54 kan meer lig op hierdie kwessies werp. Jesus se sending, soos in die Vierde Evangelie beskryf, volg klaarblyklik dieselfde geografiese struktuur soos dit in Handelinge 1:8 voorkom: die dissipels sal Jesus se getuies in Jerusalem, die hele Judea en Samaria, en tot aan die uithoeke van die aarde wees. Volgens Johannes lei Jesus se sending Hom egter na Galilea waar al God se volgelinge na sy leringe luister en tot geloof kom voor die verskeie konfrontasies met die Joodse leiers sou plaasvind soos in Johannes 5-10 beskryf.

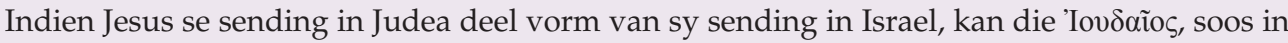
Johannes 3:25 beskryf, eerder as 'Judeër' verstaan word.

\section{The activity of Jesus in Judea (Jn 3:22-36) in recent discussion}

Jesus' activity in Judea (Jn 3:22-36) ${ }^{1}$ has not occupied very much attention in recent years. The preceding section on Jesus' dialogue with Nicodemus (3:1-21 or 2:23-3:21) has raised more interest and discussion. The same holds true for Jesus' activity in Samaria (4:1-42). ${ }^{2}$ Nevertheless, a fresh approach to 3:22-36 seems worthwhile because of the Fourth Gospel's geographical structure and of some semantic problems of the section

Recent publications on 3:22-36 are partly centred around the structure of the passage in its context (Nicklas 2002; Wilson 1981) and partly around the activity of the persons involved, in particular the baptismal activity of John the Baptist and Jesus (Gaeta 1980). Here, questions of the relation between pre-Johannine tradition and Johannine redaction come to the fore (cf. Klaiber 1990; Pryor 1997). The same holds truth for the similitude of the bride, the bridegroom and his friend in 3:29 (cf. Kempter 2008). A particular problem presents itself with the question of the relation of 3:31-36 to the preceding context. How can the words of this section be understood? Are they the continuation John the Baptist's words in 3:27-30 (Thyen 2005:232-238; Zumstein 2014:133-136), or rather theological reflections of the evangelist ${ }^{3}$ or his school (Theobald 2009:290-291), or might they even have had their original setting in the discourse of Jesus, following the dialogue with Nicodemus in 3:11-21? (Schnackenburg 1958, 1965:393-404). Whilst this last proposal does not find contemporary defenders, the question of 3:31-36, being words either of the Baptist or the evangelist, may find a solution of the fact that even words of the Baptist may appear in the

1.Further references to the Gospel of John will be indicated only by chapters and verses.

2.See the literature quoted in Beutler (2013:33-142 and 153-167), and Zumstein (2014:109-110 and 141).

3.Schnelle (2009:93), with further authors. 
language and theological framework of the evangelist. Something similar has already been the case with the words of Jesus in 3:11-21 turning into reflections of the evangelist.

The geographical setting of the scene in Judea has not aroused particular interest in recent literature. One might even be astonished that an activity of Jesus in this part of Israel is mentioned, because, according to 2:13-3:21, Jesus found himself already in Jerusalem, the capital of Judea (Kysar 1986:57; Nicklas 2002:182; with Murphy-O'Connor 1990:363).

A related problem presents itself in the occurrence of a

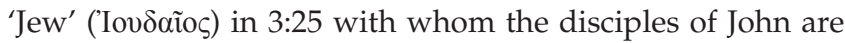
reported to be in dialogue about baptism. Generally, authors do not relate this person to the setting of the scene in Judea. ${ }^{4}$ This might change, however, if we try to find out the meaning of the geographical information of 3:22 about Jesus, coming to Judea with his disciples.

\section{Jesus' coming to Judea in John 3:22}

The first three verses of 3:22-36 are characterised by a contrast between Jesus' coming to Judea with his disciples and John the Baptist practising his ministry in Ainon near Salim. The text does not indicate the concrete area of Jesus' activity in Judea, but it may be deduced from the nature of Jesus' activity: he would practice baptism in Judea where there was enough water to baptise, and this would traditionally be the case in the Jordan Valley. For Ainon near Salim authors are uncertain, but today it is situated preferably in Samaria. ${ }^{5}$ The indication that there was much water in this place underlines the fact that John the Baptist came in order to baptise with water, different from Jesus who would come and baptise with the Spirit. The name Ainon [source] might point in the same direction.

A baptismal activity of Jesus is never mentioned in the New Testament except in 3:22 and may go back to tradition (Pryor 1997; Theobald 2009:282), because it does not play a role in the Christology of John or any of the gospels. In 4:2, the information of 3:22 is explicitly corrected and the baptismal activity attributed to Jesus' disciples. Some authors see here the hand of a later redactor (Bultmann 1964:128; Theobald 2009:297), but the evangelist himself might just as well have corrected the information of his tradition used in 3:22. It is important for him that Jesus, as the One who comes from above, gives the Spirit not by measure (3:34).

\section{Part of the geographical framework of John 2-4}

What about Jesus' arrival in Judea according to 3:22? In my view, this information forms part of the geographical framework of John 2-4 (Beutler 2013:77). In 1:35-51, we see Jesus in the area of Bethany beyond the Jordan where John the Baptist is active (1:28). The wedding in Cana brings Jesus to Galilee 2:1-11). Jesus' first semeion finds its correspondence in 4.Cf. more recently Moloney (1998:105), Thyen (2005:228ff.); Theobald (2009:285).

5.Murphy-O'Connor (2005:263-265; 2012:574-584); Thyen (2005:227), opts for a place in Judea. the healing of the official's son (4:46-54), similarly performed in Cana in Galilee. These two signs of Jesus seem to frame the whole section of John 2-4 (Brown 1966:95-96; Du Rand 1991:117).

In 2:13, a first Passover is mentioned together with the fact that Jesus and his disciples went up to Jerusalem for this occasion. Here, the cleansing of the temple takes place according to 2:14-22. Thus, we find Jesus active in the centre of Jewish faith and religion. In 2:23-25 the faith of many Jerusalemites, because of Jesus' signs, is reported, but also Jesus' lack of confidence in them, because their faith was only founded on his miraculous deeds.

The Nicodemus incident in 3:1-21 shows Jesus in dialogue with a recognised representative of the Jewish religion - even a member of the Sanhedrin - as it seems in 3:1, addressed by Jesus as 'the teacher of Israel' (3:10). In this whole section, we find Jesus in dialogue with a recognised representative of Judaism in the heart of Israel, the holy city of Jerusalem.

Jesus' move to Judea in 3:22 means the first step outside this centre of Jewish belief. He and his disciples move towards

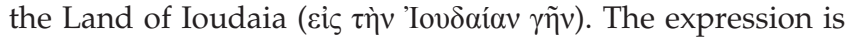
striking, because it remains unique in the New Testament. In John, the term 'Iov $\delta \alpha i \alpha$ seems to refer to Judea, the territory of the tribe of Judah. This becomes evident by the concept of 'Land', which is added in 3:22 and in comparison with other parts of Israel such as Samaria and Galilee, to which Jesus moves afterwards (4:3-42-54). In 3:22 the double term might point also to the rural area outside Jerusalem belonging to the Southern part of Israel.

\section{A move of Jesus away from the centre of Jewish belief and to the periphery}

In fact, there seems to be in John 2-4 a move of Jesus away from the centre of Israel and more and more to the periphery. The movement starts in 2:13-3:21 where we see Jesus active in Jerusalem and in conflict or dialogue with the representatives of the city: the population, as such, in 2:23-25, and, in 3:1-21, Nicodemus as a recognised representative of the Jews' leading group in the city. Whilst the response of the population, according to 2:23-25, remains rather ambiguous, Nicodemus' response seems to be missing. We see him asking a number of questions, which are answered by Jesus successively, but do not hear whether Jesus' explanations had any positive effect on him. Only later we will see that Nicodemus pleads for Jesus in the Sanhedrin without fear of personal consequences (7:50-52) and that he takes part in the burial of Jesus after his execution as a criminal (19:39ff.), thus taking a personal risk in his identification with Jesus.

Jesus' activity in Jerusalem is followed by his move towards Judea in 3:22. In the whole section, Jesus is presented only in his baptismal activity (3:23); that means in his deeds, but not in the proclamation of his message. He remains rather the object of discussions amongst John the Baptist's disciples and the mysterious 'Iovoxĩos (3:25ff.) and subsequently of 
the Baptist's words about himself and about Jesus in 3:27-30 and 3:27-36 respectively. As a whole, Jesus cannot look back to his activity in Jerusalem and Judea as being particularly successful. Not by chance, the whole section of 3:22-36 ends with the statement that nobody accepts the witness of the One who came from above (3:32), although the door also remains open to an answer of faith (3:33, 34ff.).

Jesus is on the move again in chapter 4. Firstly, we are told why Jesus is leaving Judea and making his way towards Galilee passing by Samaria (4:1-3). He is leaving Jerusalem and Judea, because he has to fear the hostility of the Pharisees who heard that he had made more disciples than John the Baptist. According to John, the Pharisees are the main adversaries of Jesus. This corresponds with the fact that they were the only Jewish group, which remained after the destruction of Jerusalem and the temple in 70 AD.

Samaria, as such, does not seem to be an independent target of Jesus' mission in Israel right from the beginning, but Jesus interrupts his travel to Galilee in order to meet the woman from Samaria and subsequently her fellow citizens and bring them to faith in him (4:4-42). Even if this whole section might have been inserted subsequently into the context between 4:1 and 4:43, it makes good sense and rounds up Jesus' program of proclaiming his message to all parts of historical Israel including the former Northern Kingdom.

There is even a certain emphasis on the encounter of Jesus with the woman at the well and the inhabitants of Sychar as taking place in Samaria. After the mentioning of Samaria at the beginning of the episode in 4:4 and of Sychar as a 'town of Samaria' in 4:5, the woman is introduced as a 'woman from Samaria' in 4:7. She is portrayed again this way twice in $4: 9$, before a comment about the lack of communication between Judeans and Samaritans. At the end of the story, 'many Samaritans' come to believe in Jesus and ask him to stay with them (4:39ff.). Thus, the whole narrative shows a strong insistence on the activity of Jesus in Samaria as such. Whilst Jesus found little acceptance in Jerusalem and Judea and had to leave that part of the country fearing for his life, he was welcomed in Samaria and found faith.

This movement continues with Jesus' arrival in Galilee. Right from the beginning, Galilee was named as the destination of Jesus' travel to the North (4:1-3). Here, Jesus had already worked his first sign (2:1-11). The place is called twice 'Cana in Galilee' $(2: 1,11)$, which sounds intentional. 'Cana in Galilee' will also be the place of his second sign and is mentioned as such in 4:46. Again there is emphasis on this location at the end of the narrative and the whole section of John 2-4 in 4:54: 'This was now the second sign that Jesus did when he had come from Judea to Galilee.' We may notice again Jesus' movement from Judea to Galilee as important for the narrator.

\section{The debated paragraph of John 4:43-45}

Thus, we are enabled to understand more easily the debated paragraph of 4:43-45. At first sight the sense seems to be clear:
Jesus moves from Samaria to Galilee and is welcomed there, mainly because of the signs which he had worked in Jerusalem and of which many Galileans had been witnesses. In this case (different from 2:23-25), the reaction of the Galileans appears in a positive light. The official's faith in 4:46-54 would then be an example of the positive reception of Jesus in Galilee. A problem poses itself in verse 44 where, as the reason for Jesus' departure for Galilee, the saying that a prophet has no honour in his own country is quoted. The debate about this verse has been treated by the present author elsewhere. ${ }^{6}$ Whilst many authors, particularly on the European continent, see in the 'country' of Jesus his home town Nazareth in correspondence with Mark 6:1-6, Matthew 13:53-58 and Luke 4:16-30, others, mainly from the Anglo-Saxon area, see in the Jesus' 'home' rather Judea or Jerusalem - the home of the prophets. ${ }^{8}$ The main reason favouring this understanding lies in the 'for'

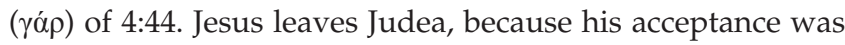
lacking and he felt in danger, as already mentioned in 4:1-3. The attempt to understand the 'for' ( $\gamma \alpha \dot{\alpha} \rho)$ of verse 44 in a rather adversative way does not really convince, according to Stimpfle (1992:91-94), although it finds some contemporary defenders (Theobald 2009:346ff.).

Judea remains a country, which occurs again in the Gospel of John more than once. Chapter 7 begins with a remarkable notice, which fully confirms the perspective of 4:1-3 and 4:43-45: 'After this Jesus went about in Galilee; he would not go about in Judea, because the Jews sought to kill him.' Jesus' brothers try to encourage him to go to Judea, nevertheless, in order to manifest himself there before his disciples, but Jesus refuses to do so for the moment (7:3). We may observe the correspondence of 'Judea' and 'Jews' (Judeans?) in verse 1, which will be discussed in the next section.

This correspondence occurs also in the remaining text (11:7ff.) According to 10:40, Jesus finds himself in an area on the other side of the Jordan. It is there that he hears about the serious illness of his friend Lazarus in Bethany near Jerusalem. After waiting three days, Jesus decides to go and see his friend: 'Let us go into Judea again.' The disciples try to warn him: 'Rabbi, the Jews were but now seeking to stone you, and are you going there again?' As at the beginning of chapter 7, Jesus answers with a reference to the hour in which his destiny will fulfil itself. What occurs to us is the repeated correspondence between

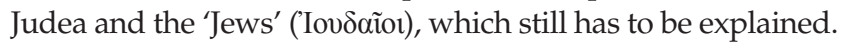

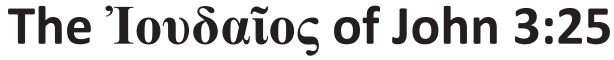 The textual evidence}

The preceding study of Judea in the Gospel of John may throw light on a particularly difficult expression in the section of

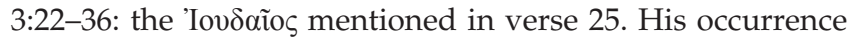
seems to have intrigued interpreters from the beginning, as

6.See the discussion in Beutler (2013:169-170).

7.The list ranges from Holtzmann (1893:85) over Bultmann (1964:150) to Theobald (2009:346ff.).

8.These authors range from Hoskyns (1940:277) to Moloney (1998:151ff.); Keener (2003:628ff.) and McHugh (2009:298). 
is manifest from the variants and conjectures in this place. ${ }^{9}$

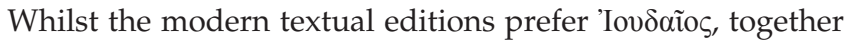
with the majority of the ancient manuscript text tradition, a considerable number of equally ancient manuscripts read

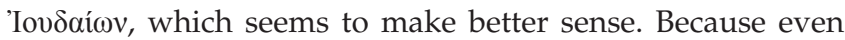

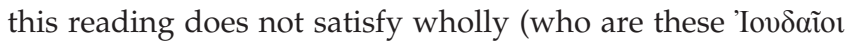
supposed to have been?), some authors, listed in Nestle-

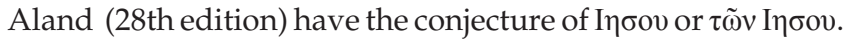
Since these conjectures lack any textual evidence, they can be discarded. In favour of the singular instead of the plural is precisely the fact that this reading appears to be the more difficult one, which, as such and besides its good attestation, should be preferred. Who, then, is this mysterious 'Iovdaĩos?

\section{The translation}

The translations ${ }^{10}$ and commentaries ${ }^{11}$ render the expression almost unanimously as 'a Jew'. This seems to be in accordance with the use of the word in the remainder of the Gospel of John and the New Testament, at least as it is supposed by the majority of scholars. However, the identity of such a 'Jew' remains obscure. He does not belong to John the Baptist's group of the disciples with whom he is presented in dialogue. His position seems to be closer to being one of Jesus' disciples, although this is not said directly in the text. It is difficult to imagine what could have been his problem with the baptism of John from the perspective of a Jew. The

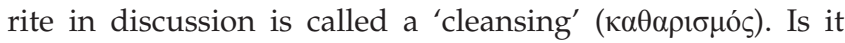
seen in the perspective of the discussions about Jewish rites of purification as reflected in Mark 7:1-5, Matthew 15:1, and further, or the opposition of the stone jars for purification and Jesus filling these jars with wine in 2:6-8? All these seem to be far-fetched. The subject of the 'strife' between the 'Iovo $\alpha$ ĩos and John's disciples seems to have been the character of John's baptism and some alternative to it - possibly the

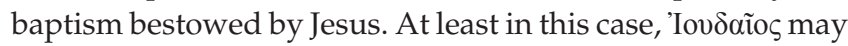
have had a different meaning, but which one?

\section{A 'Judean'}

Here we come back to our study of 'Judea' in the Gospel of John. It was Lowe (1976) amongst the first who vigorously

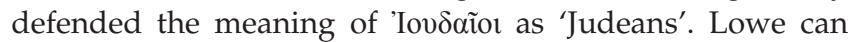
point to the fact that the vast majority John's texts, which speak of 'Iov $\delta$ ĩol, show a connection with Judea or Jerusalem. We remember the two cases quoted above in 7:1-3 and 11:7, and further. However, the evidence goes further. Besides the

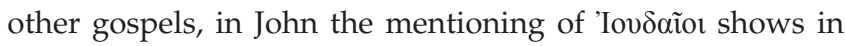
most instances a connection with Judea and/or Jerusalem. ${ }^{12}$

9.See the discussion in Nicklas (2000).

10.See for example the Jerusalem Bible, Popular Edition (1974), the German Einheitsübersetzung (1979) or the New Revised Standard Version (1989).

11.See for instance Schnackenburg (1965:451), 'ein Jude, der vielleicht aus dem judäischen Bereich kam, wo Jesus taufte'; Brown (1966:152) 'a certain Jew' (referring back to Schnackenburg); Moloney (1998:109) or Thyen (2005:228ff.).

12.They are listed in Lowe (1976:121ff.). He mentions, amongst other instances, the

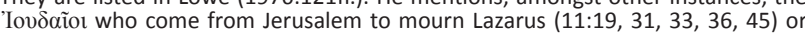
those who attend the Feast of Dedication (10:22, probably identical with those of $10: 19,24,31,33$ ) - sometimes people from Jerusalem (cf. $7: 25,11,13,15,35$ ). $10: 19,24,31,33)-$ sometimes people from Jerusalem (cf. $7: 25,11,13,15,35)$.
The fear of the 'Iovóĩo takes place four times in Jerusalem (7:13; 9:22; 19:38; 20:19, etc.)
This is particularly the case in the instances where we find Jesus or John the Baptist in conflict with a leading Jewish group residing in Judea or Jerusalem, increasingly opposed to the mission of, firstly, the Baptist and then of Jesus. It is neither possible nor necessary to list all these texts. Already in 1:19 we see John the Baptist exposed to an inquiry about his person and his mission by some priests and Levites, sent

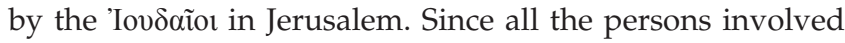
are Jews, the term seems to have a geographical connotation.

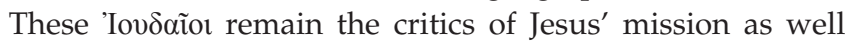
throughout the whole of the Fourth Gospel, particularly in the great controversies of chapters 5 and 7-10.

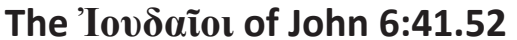

An exception seems to be the 'Iov $\delta$ aior of 6:41, 52 as the critical listeners to Jesus during his discourse on the bread of life in John 6 . These are the only instances where we find

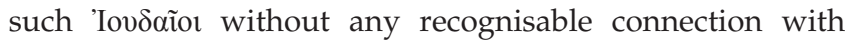
Judea or Jerusalem. ${ }^{13}$ This fact may be explained by the hypothesis that the whole chapter 6 of John was added to its context at a later stage (Beutler 2007). ${ }^{14}$ A strong argument in favour of this hypothesis is the fact that, in 6:4, we find a passover feast, which is inserted into its narrative context only with difficulty. Starting with 2:13, Jesus seems to go up to Jerusalem for the Feasts of Pilgrimage in the cycle of a year: after the first Passover there is the unnamed feast of $5: 1$, which seems to have been the Pentecost. If we pass by $6: 4$, we see Jesus in pilgrimage to the Feast of Tabernacles in $7: 2-10$. He remains in the holy city until the of the temple's Feast of the Dedication in 10:22 and returns to Judea and Jerusalem for the celebration of his last Passover in 11:55 after the raising of Lazarus from the dead in 11:1-42.

All these feasts are feasts of the 'Iov $\delta$ ĩor, according to John (see 2:13; 5:1 - feast without name; 6:4; 7:2; 11:55). ${ }^{15}$ This could well have a geographical connotation as emphasised by Lowe (1976). They are in fact celebrated in Jerusalem,

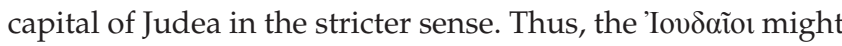
as well be called 'Judeans'. The problem of the 'Feast of the

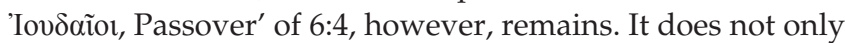
not fit into the annual cycle of Jewish feasts in the public life of Jesus, according to John, but interrupts this cycle of pilgrimage feasts, because Jesus does not seem to have the intention of going up to Jerusalem on this occasion. Besides this observation, there are several reasons to presume that John 6 is a 're-reading' of its narrative context. Not only does the chapter not fit into its context of chapters 5 and 7 - a reason for occasional proposals to read chapter 6 after John 4 . Instead of the Jewish Passover we have, in John 6, Eucharistic motifs, not only in the pericope of the multiplication of the loaves, but, also and in particular, in the verses about eating

13.This fact is also seen by Lowe (1976:122ff.) who presumes some Judean background of Jesus' opponents in John 6. Bultmann (1964:170) sees in them simply 'Jews' without geographical connotation. By moving John 6 before John 5 , he prepares the ground for the controversies of John 5:7-10 in Jerusalem.

14.Now also in Beutler, J., 2012, Neue Studien zu den johanneischen Schriften New Studies on the Johannine Writings, pp. 165-180, Vandenhoeck \& Ruprecht, Göttingen. (Bonner Biblische Beiträge, 167).

15.Only in John 10:22 the expression is missing. 
Jesus' flesh and drinking his blood in 6:51-58. The writer seems to have inserted here the Eucharistic tradition of his community, which was missing in the passion account of John 13. Right through the chapter, there is a strong dependence on synoptic tradition, particularly in Mark 6:30 8:33. Peter appears in a positive light, different from the rest of John 1-20, but in accordance with the equally additional chapter, John 21 . These are the reasons why the present writer proposed some time ago to see in John 6 a 're-reading' of the narrative context of the chapter. ${ }^{16}$ The chapter shows a shift of emphasis from the Jewish Passover celebrated in Jerusalem to the Christian Eucharist, now mentioned in the context of Galilee - home of important early Christian communities by the time of the final redaction of the Gospel of John.

\section{'Iovא反ĩot in John}

If we move back from these considerations to the meaning

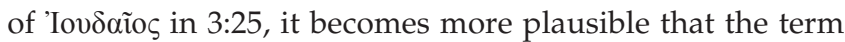
should mean 'Judean'. Beyond John 6 this meaning is always recommended where we find 'Iov $\delta$ ĩor in John, together with a reference to the area of Judea, in our case mentioned in 3:22.

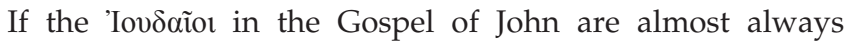
rendered by the translations and commentaries as 'Jews', this is because, outside the Gospel of John and perhaps some gospel text, ${ }^{17}$ the term seems to designate almost every time 'Jews' as members of the Jewish religion or the Jewish people. This leads to the hypothesis that, from early times

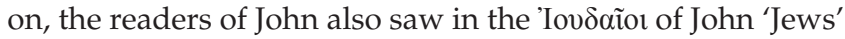
in general (see Beutler 2001). ${ }^{18}$ The reference to Judea and

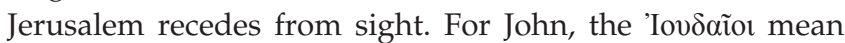
either inhabitants of Judea and Jerusalem or a specific group residing in Jerusalem or its surroundings having authority in religious matters and opposing Jesus and his mission. Perhaps the best example of this meaning is found in John 9: the narrative of the healing of the man born blind. He himself is a Jew, and so are his parents and neighbours, Jesus himself

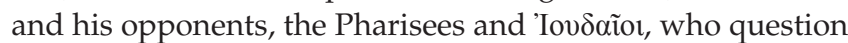

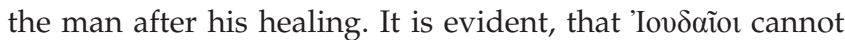
mean here simply 'Jews', because they form a group inside the Jews of Jerusalem. Putting them in quotation marks may help to grasp this particular usage of John in such texts, but it might be worthwhile considering the proposal of Lowe (1976) to opt for 'Judeans'.

It is probable that the first readers of John were still aware

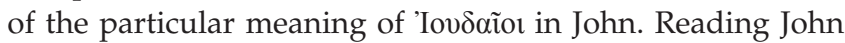

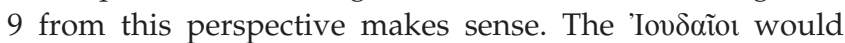
then stand for a group located in and around Jerusalem concerning this hypothesis.

17.Lowe (1976:126ff.) points to Matthew 18:15, Mark 7:3 and possibly Luke 23:51.

18. My contribution there makes part of a seminar on 'Anti-Judaism in the Fourth Gospel' from January 2000 at Leuven University and published one year later in the Netherlands as J. Beutler, 2012, Neue Studien zu den johanneischen Schriften New Studies on the Johannine Writings, pp. 69-77, Vandenhoeck \& Ruprecht, Göttingen. (Bonner Biblische Beiträge, 167). who distinguished themselves by their opposition to Jesus and his claims. It was only at a later time that the readers of the whole New Testament came across the passages about

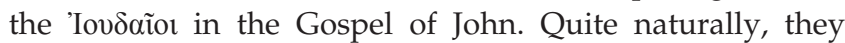
interpreted those passages of the Fourth Gospel in the sense of the remainder of the New Testament. The consequences were extremely serious. It was no longer a group of leading Jews or Judeans in Jerusalem who opposed Jesus, tried to stone him and eventually brought him to the cross with the cooperation of the Roman occupying power, but the 'Jews'

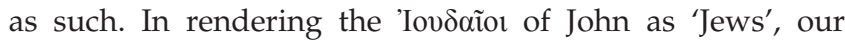
language runs the risks of contributing to anti-Judaism with all the pernicious consequences of which we are aware (cf. again Lowe 1976:130).

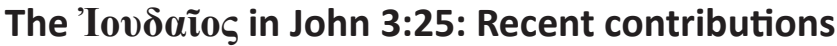

If we return to our verse 3:25, it is appropriate to see in the

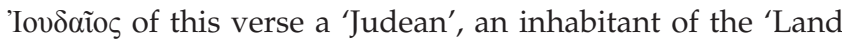
of Judea', mentioned in 3:22. Since the disciples of John the Baptist are represented as being in controversy with him, he might even be an adherent of Jesus with his differing understanding of baptism. What cannot be attributed to him is a particular connection with Judaism.

It is astonishing to see that modern translations and commentaries are rather unaware of the geographical connotation of the 'Iov $\delta$ ĩo of 3:25. One exception is found in the commentary of Wengst (2000) who elsewhere too is conscious of the aspects of Judaism in the Gospel of John. In his translation of 3:25, the author speaks of a 'Jew', with whom John's disciples are in controversy. In his comment, however, he identifies him first as a 'Jew', but then adds that this person should rather be represented more precisely as a 'Judean'. Here we are on the right track (Wengst 2000:154). Other authors may be added here. Amongst them see Von Wahlde (1982:46-50) in his detailed article. Further

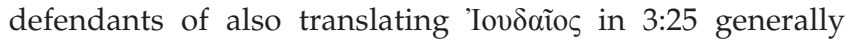
and consequently with 'Judean', are Malina \& Rohrbaugh (1998:44-46, 93). They also refer to Flavius Josephus as

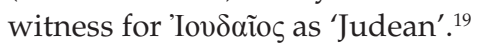

The best and most detailed study of the meaning of the

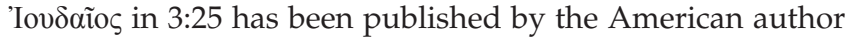
Mark Appold in his contribution to the recent volume Character Studies in the Fourth Gospel (2013). First of all, Appold notices the problems connected with the identification of the

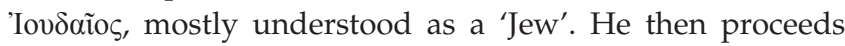

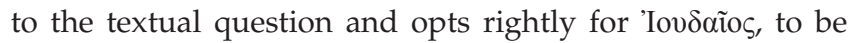
preferred, being the most probable reading. He then asks for the best translation of the term in 3:25 and opts with good reasons for 'a Judean', even if this geographical sense cannot be maintained in all the instances of the word in the Gospel of John. The man might have come from Jerusalem, but have

19.See page 45 their reference to the 'Life' of Josephus. References that are more precise are given by Lowe (1976:105ff.). For the 'Life' of Jophus, see vit. 346 a precise are given by Low ' (1976:105.). For the' Life' of Josephus, see vit. 346 and 17:254f. Josephus distingush' $17.254 f$. Josephus distinguishes between Galleans, Idumeans and people from Jericho or Perea, who then are joined by the 'Iovdoĩot themselves. A similar use is attested in $A J$ 18:2. 
gone out to the desert in order to find out about the baptism of John and possibly the one bestowed by Jesus. This is the most probable meaning of the 'purification' mentioned as object of strife between the disciples of the Baptist and the 'Iovdaĩos. The man himself does not speak in this whole episode, but John the Baptist himself takes up the subject and declares himself to be nothing more than the friend of the bridegroom. He appeals to his listeners as his witnesses that he had said that he was not the Messiah, but only the one

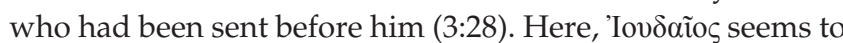
be part the Baptist's audience and of the group of witnesses of his teaching. This brings him close to the group of Jesus' first disciples. Just as some of them remained anonymous, so he too remains without name. One might speculate whether he was even identical with one of the anonymous disciples of Jesus mentioned in the Fourth Gospel or early Christian tradition such as John the Elder. Here we lack evidence. The author of the Fourth Gospel might have had his reasons for concealing the names of some of the closest followers of Jesus. We have to respect his decision.

\section{Conclusion}

At one point, a further development of the approach of Mark Appold (2013) is still possible. We saw a close connection between Jesus' coming to Judea in 3:22 and the appearance of the 'Iov $\delta$ ĩo $\varsigma$ in 3:25. In fact, the importance of Judea as the scenery of an important part of the missionary activity of Jesus merits to be elaborated with more emphasis. As we have tried to show, Jesus' activity in John $2-4$ is described as one in concentric cycles. Jesus starts his activity in Jerusalem, the heart of Judea, where he finds little positive response and faith. Then he moves to the countryside of Judea where he gains some acceptance in his baptismal activity, but is not presented as a preacher - only as the object of John's witness. By contrast with this first part of Jesus' mission in the Holy Land, Jesus finds warm acceptance on the part of the Samaritans, and the same holds true for his welcome in Galilee. ${ }^{20}$ If these observations are correct, the fourth evangelist shows us Jesus, the Word become flesh (1:1-18) after an initial beginning in the Jordan Valley and in Galilee (1:35-2:12), on a way that takes him from the centre of Jewish faith and religion to the periphery, to the outskirts. ${ }^{21}$ Under this aspect, John might be closer to the Synoptic Gospels and to Paul than sometimes thought.

\section{Acknowledgements Competing interests}

The author declares that he has no financial or personal relationship(s) that may have inappropriately influenced him in writing this article.

20.This development is also seen by Neyrey (2009:66). According to the author, "Judea' and 'Galilee' are not just places, but have a symbolic meaning: 'in "Galilee" Jesus is accepted, gains disciples and remains; in "Judea" he is harassed, put on trial, and killed. He does not remain in "Judea"'. Already before him, Keener (2003:628) judged: 'Untrustworthy disciples (2:23-3:9) and hints of hostility (4:1-3 characterized Jesus' reception in Judea; Samaria (4:4-42) and Galilee (4:43-54)
received his ministry.'

21.This perspective underlies the commentary of Beutler (2013), whose English translation will be published by W.B. Eerdmans, Grand Rapids, Michigan.

\section{References}

Appold, M., 2013, “'A Jew": A search for the identity and role of an anonymous Judean', in S.A. Hunt, D.F. Tolmie \& R. Zimmermann (eds.), Character studies in the Fourth Gospel, pp. 260-267, Mohr Siebeck, Tübingen. (Wissenschaftliche Untersuchungen zum Neuen Testament, 314).

Beutler, J., 2001, 'The identity of the "Jews" for the readers of John', in R. Bieringer, D. Pollefeyt \& F. Vandecasteele-Vanneuville (eds.), Anti-Judaism and the Fourth Gospel: Papers of the Leuven Colloquium, 2000, pp. 229-238, Royal van Gorcum Assen, NL. (Jewish and Christian Heritage Series, 1).

Beutler, J., 2007, 'Joh 6 als christliche "Relecture" des Pascharahmens im Johannesevangelium', in R. Scoralick (ed.), 'Damit sie das Leben haben' (Joh
10,10): Festschrift für Walter Kirchschläger zum 60. Geburtstag, pp. 43-45, Theologischer Verlag, Zürich.

Beutler, J., 2013, Das Johannesevangelium: Kommentar, Herder, Freiburg/Basel/Wien.

Brown, R.E., 1966, The Gospel according to John (i-xii): Introduction, translation and notes, Doubleday, Garden City, New York. (The Anchor Bible, 29).

Bultmann, R., 1964, Das Evangelium des Johannes, Vandenhoeck \& Ruprecht, Göttingen. (Kritisch-exegetischer Kommentar über das Neue Testament. Begründet von Heinrich August Wilhelm Meyer, Zweite Abteilung, 18, Auflage).

Du Rand, J., 1991, Johannine perspectives: Introduction to the Johannine writings Part 1, Orion, Doornfontein.

Gaeta, G., 1980, 'Battesimo come testimonianza: Le pericopi sul Battista nell'evangelo di Giovanni', Cristianesimo nella storia 1, 279-314.

Holtzmann, H.J., 1893, Evangelium, Briefe und Offenbarung des Johannes, Mohr Freiburg, Leipzig. (Hand-Commentar zum Neuen Testament, 4, zweite und verbesserte Auflage).

Hoskyns, E.C., 1940, The Fourth Gospel, ed. F.N. Davey, 2 vols., Faber \& Faber, London. Keener, C.S., 2003, The Gospel of John: A commentary, vol. 1, Hendrickson, Peabody, MA. Kempter, M., 2008, 'La signification eschatologique de Jean 3.29', New Testament Studies 54(1), 42-59. http://dx.doi.org/10.1017/S0028688508000039

Klaiber, W., 1990, 'Der irdische und der himmlische Zeuge: eine Auslegung von Joh 3, 22-36', New Testament Studies 36, 295-233.

Kysar, R., 1986, John, Augsburg Publishing House, Minneapolis, MN. (Augsburg Commentary on the New Testament).

Lowe, M., 1976, 'Who were the IOYAAIOI?', Novum Testamentum 18, 101-130.

Malina, B.J. \& Rohrbaugh, R.L., 1998, A social science commentary on the Gospel of John, Fortress Press, Minneapolis.

McHugh, J., 2009, A critical and exegetical commentary on John 1-4, ed. G. Stanton, T\&T Clark, London. (The International Critical Commentary on the Holy Scriptures of the Old and New Testament).

Moloney, F.J., 1998, The Gospel of John, Liturgical Press, Michael Glazier, Collegeville, Minnesota. (Sacra Pagina Series, 4)

Murphy-O'Connor, J., 1990, 'John the Baptist and Jesus: History and hypotheses', New Testament Studies 36(3), 359-374. http://dx.doi.org/10.1017/S0028688500015794

Murphy-O'Connor, J., 2005, 'Sites associated with John the Baptist', Revue Biblique $112(2), 253-266$

Murphy-O'Connor, J., 2012, 'Place-names in the Fourth Gospel (I): Aenon near Salem (John 3:23)', Revue Biblique 119(4), 564-584.

Neyrey, J.H., 2009, The Gospel of John in cultural and rhetorical perspective, W.B. Eerdmans, Grand Rapids, MI, Cambridge.

Nicklas, T., 2000, 'Notiz zu Joh 3,25', Bibliotheca Ephemerides Theologicae Lovanienses 76, 133-135.

Nicklas, T., 2002, 'Literarkritik und Leserrezeption: Ein Beitrag zur Methodendiskussion am Beispiel Joh 3, 22-4,3', Biblica 83, 175-192.

Pryor, J.W., 1997, 'John the Baptist and Jesus: Tradition and text in Joh 3, 25', Journal for the Study of the New Testament 19(66), 15-26, October.

Schnackenburg, R., 1958, 'Die "situationsgelösten" Redestücke in Joh 3', Zeitschrift für die Neutestamentliche Wissenschaft 49(1), 88-99.

Schnackenburg, R., 1965, Das Johannesevangelium: 1. Teil. Einleitung und Kommentar zu Kap. 1-4, Herder, Freiburg /Basel/Wien. (Herders Theologischer Kommentar zum Neuen Testament, IV/1).

Schnelle, U., 2009, Das Evangelium nach Johannes, Evangelische Verlagsanstalt, Leipzig. (Theologischer Handkommentar zum Neuen Testament, 4).

Stimpfle, A., 1992, 'Das "sinnlose" yóp in Joh 4,44: Beobachtungen zur Doppeldeutigkeit im Johannesevangelium', Biblische Notizen 65, 86-96.

Theobald, C., 2009, Das Evangelium nach Johannes: Kapitel 1-12, übersetzt und erklärt, Pustet, Regensburg. (Regensburger Neues Testament).

Thyen, H., 2005, Das Johannesevangelium, Mohr Siebeck, Tübingen. (Handbuch zum Neuen Testament, 6).

Von Wahlde, U.C., 1982, 'The Johannine "Jews": A critical survey', New Testament Studies 28(1), 33-60. http://dx.doi.org/10.1017/S0028688500007244

Wengst, K., 2000, Das Johannesevangelium: Erster Teilband: Kapitel 1-10, W. Kohlhammer, Stuttgart. (Theologischer Kommentar zum Neuen Testament, 2. Auflage).

Wilson, J., 1981, 'The integrity of John 3:22-36', Journal for the Study of the New Testament 3(10), 34-41. http://dx.doi.org/10.1177/0142064X8100301004

Zumstein, J., 2014, L'évangile selon Saint Jean (1-12), Labor et Fides, Genève. (Commentaire du Nouveau Testament, IVa, Deuxième série). 